\title{
Analysis of The Effects Debt Capital, Equity Capital on Residual Income and It Is Impacts on Amount Coperative Member
}

\author{
Adih Supriadi \\ Faculty of Economic and Business, Sultan Ageng Tirtayasa University, Indonesia \\ Email: adihs84@untirta.ac.id
}

\begin{abstract}
The researchs is find out the effects of DC and EC on residual income (SHU) and it is impacts on amount coperative member. The researchs is descriptif quantitativ, the population used as the units of researchs analyzis is a coperative in the city of Tangsel with criteria coperatives that have many business units, and always hold annual member meetings for the last five consecative years, namely 2016 to 2020, as for the numbers of coperatives that will be sampled in this researchs are fifty coperatives. This research uses the methode asociative causall analitycal which mean a causall relationships wherein the variables $X$ would effects variables $\mathrm{Y}$ and variables $\mathrm{Y}$ would effects variables $\mathrm{Z}$. This methode is find out the relationships among two or more variables, by explining, predicting along controling symptoms. From researchs result it was found that DC partial significants effects on residual income, withal determinations coefficients is $72,29 \%$, the rest $27,71 \%$ influence by others factor. EC partiall significants effects on residual income, withal coefficients of determinations is $74,67 \%$, the rest $25,33 \%$ influence by others factor. DC and EC simultaneouly significants effects on residual income, withal coeficient of determinations is $81,81 \%$, the rest $18,19 \%$ influence by others factor. Residual income partial significants effects on amount coperative member with a coeficient of determinations is $41,82 \%$, the rest $58,18 \%$ influence by others factor.
\end{abstract}

Keywords: Coperative, DC, EC, Residual Income, Coperative Member

\section{INTRODUCTION}

Coperatives play a very strategic role in the Indonesian economy, so this should be the focus of economic development. Herdianto (2013) explains coperative role in national economic, namelly it is positioning as a main played in economy activitie in variouses sector, a provide of employments, an importants player in developments in home grown economy activitie and communities empowerments, author of new market and source innovations, it is contributions to maintining balanced of payment throughs exports activitied.

UU No. 25 of 1992 about coperatives) it was explained that coperative is a bussines entitied whice member are people or coperative legals entitied based on activitied coperative principles wells a people economy movements based on the principles of kindship. Coperatives aims advances to welfared on member particulared and societis in generals and participat in developments the nationals economy on occasion the contexts realizes in advances, fair and prosperousis societis based on Pancasila and UUD 1945.

There're many coperatives are inactived or underdevelopes for this the increased in the quantities coperatives isn't acompanied by an increased qualities and comparables activitie. That mattered indicated lack of public trust of coperating, as well minimally levels activities and participations of coperative member as owner and user of coperative servicess, coperatives member as playing a role in the developments coperatives. 
Working capital owned by coperatives will effect the development of cooperatives, eithers it is EC or DC. Riyanto (2007) statements lest definitions on working capital is define as totals amounts currents asset. This definitions is similar as definitions working capital statement by Irawati (2006) working capital is a companies investments of currents asset. Tria Rohmansyah (2017) in the researced result explains that explained DC and EC togethers have a positiv significants effecst on residual income. But in this researches the effects on amount coperatives member is not found.

Capital is importants aspects on coperative expenditur managements, if the coperative can not maintained a satisfactori levels of capitals, than the coperative is like tobe an insolvent statement (un able to pay the maturing obligations) maybe even have to be liquidate or bankrupts (Tria Rohmansyah 2017). In coperatives one of the roles of capitals guaranted bussines continuities on regards to used capitals, so as to determined sufficients capitals. As much greats tier of efficiencies and effectivies of the use of capital that must be managed by coperatives is a problema be found by coperatives (Pertiwi 2017).

UU No. 25 of 1992 about coperatives)It is explaines the source of coperative capitals consistences of EC and DC. EC can of: principals saving, mandatories saving, reserves fund, and granties. DC can of: member, others coperatives and/or their member, The banks and institution, issuances of bonds and others debt security, other legals source. On coperative, DC and EC conditioned can affects residual income obtaine by the coperative, the size and amount of the remaining income of the coperative. Syarifuddin (2019) in his researched explaines lestt partialy or simultaneouly the variable of services qualities, trusted and bussines results have a positive and significants effects on members satistfaction. But, in this researched, the impacts residual income on amount coperatives member is not found. Based on this, the author will conduct research on analysis of the effect DC, EC on residual income (SHU) and it is impact on amount coperative member.

\section{LITERATURE REVIEW}

\section{Coperative}

Coperative are people's economy organizations that are socials characters, consists of people's or coperatives legals entitied as constitutes in economy arrangements as efforts together on the basis of principles kindship (UU No. 25 of 1992 about coperatives). In anothers sensed, coperatives is a bussines entities whice member are individuals or coperative legals entities on the basis it is activitie on the basis coperative principles as well as a peoples economy movements on the basis of principles kindship. Herdianto (2013) explaining that coperatives are organizationt of mutuals helped carried out bussines a groups, whats on the basis concepts of helped. Activity in commercials matter are sollely for the economy purposed, not to the socials purposed of mutuals coperations.

\section{Coperative Member}

Coperative member are owner and user of coperative servicess. As owner and user of coperative servicess, member participated activelly in coperative activities. Even so, as long as it does not harms it is interest, the coperative can also provid servicess for non member accordingly to natures of it is bussines activites, for intentions of attracting non member tobe come member of coperative (Buchari 2020). Coperative memberships on the basis commons economy interest with in the scopes of the coperative's bussines. Every members has an obligation and equal rights to coperatives as stipulate from article associations. In UU No. 25 of 1992 about coperatives) explaine severals thing abouts coperative member as follow:

1) Coperative member is owner along user of coperative servicess. 
2) Coperative memberships on the basis commond economy interest with in the scopes for coperative's bussines.

3) Coperative memberships can obtaine or terminate afters requirepments as stipulate in the articles associations as meets.

4) Coperative memberships isn't transferables. But if coperative members died, his memberships can continued by on heirs who meeted the requirepments from articles associations.

5) Every members has an obligation and equal rights to coperatives as stipulate from article associations

6) Members meetings is high authorities from coperative.

\section{Residual Income (SHU) of the Coperative}

Groundes UU No. 25 of 1992 about coperatives,)residual incomes from the coperative in coperative's incomes earne in one financials years minust cost, depreciations, and others liabilitie include tax from financials years concern. The residual incomes after deducted the reserved funds, is distribute between member in proportions to the bussines services performent on members at coperative, and is using form coperative educationed purpose and others purpose of the coperative, in accordanc at decision on member meetings (Buchari 2020). residual incomes isn't a diviened in the form of profit deriveds on result of invested in share happening in limited company, however residual income is bussines profits lest divide accord to the economy activities coperative member. then the amounts of residual income receivied by eachs members can be differents, the incomes obtainable from residual incomes rely on total of capital participationt and members transactionst on formationt of coperative incomes, the higher transaction of members with the coperative, the higher residual income that members would received (Ni Made Taman Ayuk 2011). It is clear differents from others bussines entity, wherein dividend earn shareholder are proportionals, rely on the amounts of capital they save. This is differen among coperatives and others bussines entities. Other than that, in others bussines entities, the terms residual income on profits. An income statements is a reports that provides informations about the company's revenues, expenses, and profits during a certain periode. Wells qualities earning in financials statement are profit that do reflects the curren states of the firm and are independent in manipulations by managements then these profit could use for decisions maked (Alvin and Hendang T, 2019). Things that becomed the principle of residual income coperative :

1. Residual income distributed is came from member

2. Residual income member are servicess from capital and bussines transactiont carring by member them selved.

3. The distributiont of residual income member is done transparently and openly

\section{Capital}

Funds using to finances the procurements of asset and operation a corporation. Capital is claim or share owned by the owners of the corporation in the capital stock, retained earnings or profit or excess asset owned by the corporation toward all it is debts (Munawir 2004). Riyanto (2007) explaining lest types of capital consist from :

1. Debt capital

is capital whice comed from out corporation whose is temporarry working in the corporation, and for corporation concerne, capital is debt that should repaired in times. Trade payables are sacrifices of tomorrow economy advantage that might appear from the entities current obligations to give asset or give servicess to other entities in tomorrow as a results of last transactions.. In terms of utilization fund, the funds 
utilization corporation originated from short-term and long-term, both form a structure that the corporation would used to execute it's bussines properlly for operationt and investments (Haslinda 2020).

2. Equity capital

is capital whice comed on the owners corporation and is embedde corporation for indefinit periode of times. In terms of liquidity, own capital is a long-term funds whice liquidities is uncertain. EC originating from internal corporation, is the capital generates by the corporation it self in the form of profit generates by the corporation.

\section{Researchs Frame Work And Hypotheses}

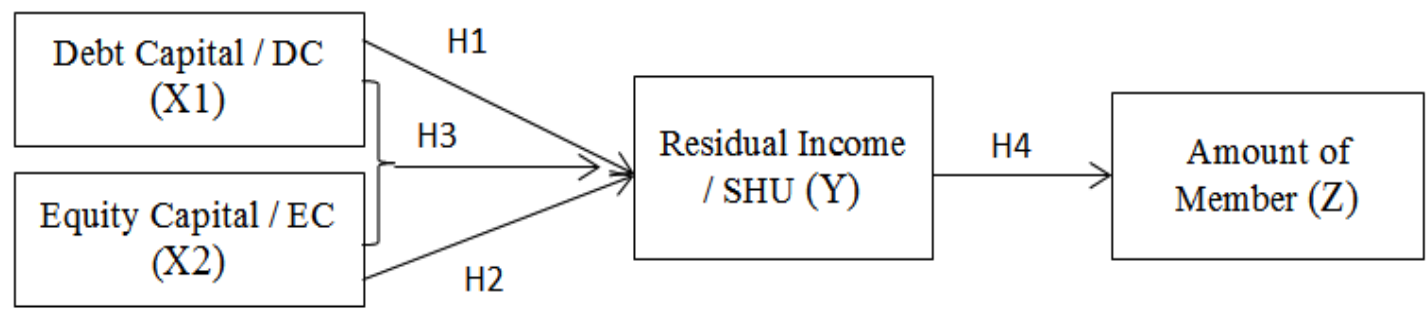

Image Researchs Frame Work

\section{The Effects of DC Partialy on SHU}

Is capitals that comes from outsides the corporation whice temporrarily worked insides the corporation, toward corporation concer capitals a debt which must be repair on times (Kartawinata, 2020). Residual income of the Coperative's tobe Coperative's income earning in one financials years minust cost, depreciationt and others liability include tax in the financials years concern (UU No. 25 of 1992 about coperatives). Researchs results Raidayani (2017) that working capital, absolute and significants effects on residual income of the coperative. Whereas researches results Tria Rohmansyah (2017) that loan capital has significants effects on the residual income. Be based explanation above, a hypothesist can be formulated, as follows :

$\mathrm{H}_{1}$ : There is a significants effects of DC on SHU

\section{The Effects of EC Partialy on SHU}

Is capital that come from the owners of the corporation and is embeded in the corporation for an indefinit periode of times, (Riyanto 2007). Differenced SHU In opinion Raidayani (2017) is incomed receives by coperative for one periode, reduce expensed in one periode. Tria Rohmansyah (2017) in his researched, it was explaine that EC has absolute and significants effects on the SHU. Pertiwi (2017) in his researched explaine that EC has an influences on the residual income, in case increased in one rupiah of owned capital with constant assumption, can be reduced to residual incomes from the bussines. EC is influentials in predict change in profits in the next one to two years, by reason stage of EC can results transformation in increased profit, whereas a decreased in EC can results in change in decrease profit, (Lucia Ari Diyani 2016).

Be based explanation above, a hypothesist can be formulated, as follows :

$\mathrm{H}_{2}$ : There is a significants effects of EC on SHU 


\section{The Simultaneouly Effects of DC and EC on SHU}

Many relates research have been carried out on the effects of DC and EC simultaneouly on SHU, like the result of F-test researched carried out on by Tria Rohmansyah (2017) explaining lest EC and DC togethers has absolute and significants effects on SHU. DC and EC has a significants effects on profits accretion (Cahyaningrum, Hesti 2012). Be based the result of test carrie out Henry Yahya (2015) lest EC and DC has influenced on corporation profits growths. The corporation did experienced an increased on count profits expensed due to DC, still as effects of increase capital has to increased profit due to corporation running smooth in bussines. Be based explanation above, a hypothesist can be formulated, as follows: $\mathrm{H}_{3}$ : There are a significants effects of DC and EC simultaneouly on SHU

\section{The Effects of SHU Partially on Amount of Coperative Member}

Coperative member are owner and user of coperative servicess (UU No. 25 of 1992 about coperatives). As owner and user of coperative servicess, member participated activelly in coperative activity. As long as it's not detrimentals to it is interest, a coperative get too provided servicess to non member in compatible with the natures of it is bussines activity, withal the intentioned to interesting non-member becomes member of the coperative. Residual income is bussines profits that is dividen in accord lest to the economy activity of the coperative member. Then the amounts of residual income receivied by eachs members can be differents, the incomes obtainable from residual incomes rely on total of capital participationt and members transactionst on formationt of coperative incomes, the higher transaction of members with the coperative, the higher residual income that members would received (Ni Made Taman Ayuk 2011).

Be based explanation above, a hypothesist can be formulated, as follows:

$\mathrm{H}_{4}$ : There are significants effects of SHU to amount of coperative member

\section{RESEARCH METHODS}

The researchs is to find out the effects of DC and EC on residual income (SHU) and it is impact on amount coperative member. Suitable to this purposed, This research uses the methode asociative causall analitycal which mean a causall relationships wherein variables $X$ would effects variables $\mathrm{Y}$ and variables $\mathrm{Y}$ would effects variables $\mathrm{Z}$. This methode is to find out the relationships among two or more variables, by explining, predictyng along controling symptoms. In this research, the calculationt was donen't manualy, however utilize a tools is Eviews applications, untill hoped that the results obtainable are more accurates. The resource of data worn is secondary data it is coperative financials statements. The sampling and populationt worn researched analysist unit are coperatives in Tangsel City with criteria of coperatives lest routinelly carred out RAT for five consecutif years, scilicet 2016 to 2020, as for the numbers of coperatives that will be sampled in this researchs are fifty coperatives.

\section{RESULT AND DISCUSSION}

In this matter, some check element like partialy check of penel data (t-test), simultaneously penel data test (F-test), penel data regressiont model checking, penel data checking of coefficients of determinationt and correlationt. The checking process use Eviews8 software to obtain more accurated and checked result. 


\section{The Effects of DC Partialy on SHU \\ T- check}

The t- check or partials regressiont coefficients check used to determined whether partialy the independently variables a significants effects on the dependently variables or not. To know the effects of DC partialy on SHU, a partial statistical check can be done ensuing:

Be based probability values ( $\mathrm{p}$-values). The hypothesist check:

$\mathrm{H}_{0}$ : Partialy DC doesn't have a significants effects on SHU

$\mathrm{H}_{1}$ : Partialy DC has a significants effects on SHU

The hypothesist check terms :

If the p-values < 0.05 ; so $\mathrm{H}_{0}$ is rejected and $\mathrm{H}_{1}$ is received

If the p-values > 0.05; so $\mathrm{H}_{0}$ is received and $\mathrm{H}_{1}$ is rejected

In this matter partialy whether DC variables a significants effects or not on the SHU. For more detail, look the table ensuing:

Table 1. The Effects of DC on SHU

\begin{tabular}{lrlll}
\hline \hline \multicolumn{1}{c}{ Variable } & Coefficient & Std. Error & t-Statistic & Prob. \\
\multicolumn{1}{c}{ C } & 19.49006 & 3.628854 & 5.370856 & 0.0000 \\
\multicolumn{1}{c}{ DEBT_CAPITAL } & 0.011230 & 0.032311 & 2.347564 & 0.0294 \\
& Effects Specification & & \\
Cross-section fixed (dummy variables) & & & \\
R-squared & 0.722951 & Mean dependent var & 20.59978 \\
Adjusted R-squared & 0.582078 & S.D. dependent var & 25.30822 \\
S.E. of regression & 16.36097 & Akaike info criterion & 8.694292 \\
Sum squared resid & 15793.21 & Schwarz criterion & 9.555337 \\
Log likelihood & -360.2431 & Hannan-Quinn criter. & 9.041516 \\
F-statistic & 5.131950 & Durbin-Watson stat & 2.334261 \\
Prob(F-statistic) & 0.000000 & & \\
& & & \\
\hline \hline
\end{tabular}

Sumber: diolah dengan Eviews

At table 1 above, can be observed that the probabilities values of DC or p-values DC is $0.0294<0.05$ so $\mathrm{H}_{0}$ is rejected and $\mathrm{H}_{1}$ is received, signify DC has a significants effects on SHU.

Ratio of t-count with t-table. Hypothesist check is :

$\mathrm{H}_{0}$ : Partialy DC hasn't effects on SHU

$\mathrm{H}_{1}$ : DC partialy effects on SHU

The hypothesist test terms :

If $\mathrm{t}>\mathrm{t}$-table, so $\mathrm{H}_{0}$ is rejected and $\mathrm{H}_{1}$ is received

If $\mathrm{t}<\mathrm{t}$-table, so $\mathrm{H}_{0}$ is received and $\mathrm{H}_{1}$ is rejected

To know values of $t$-table could be obtaine by used the provisiont t-table $=(\alpha ; \mathrm{df})$, wherein $\alpha$ values is $5 \%$ or 0.05 and the df values is (nk), wherein $\mathrm{n}$ is the numbers of observationt and $\mathrm{k}$ is the numbers of variable utilized. At table 1 mentioned, it could in view that the t-statistic of the DC is 2.347564. Whilst the t-table values is: t-table $=(\alpha ; \mathrm{n}-\mathrm{k})=(0.05 ; 90-4)=(0.05$; $86)=1.66277$. So t-count $>$ t-table that is $2.347564>1.66277$ then $\mathrm{H}_{0}$ is rejected and $\mathrm{H}_{1}$ is received, signify that DC partialy has a significants effects on SHU. 


\section{Determinationt coefficients check}

The coefficients of determinationt showing the percentages of the independently DC variables using in the models capable to explained the dependents variables SHU. At table 1 above, the dimensions of $\mathrm{r} 2$ is 0.722951 , this showing that the percentages contributiont of the influences of the independents variables DC to the dependents variables residual income is $72,29 \%$ or it could meaning lest the independents variable utilized in models are able to explained the total $72,29 \%$ to the dependents variables, the rest $27,71 \%$ is affected by others factor beyond the regressiont models.

\section{The Effects of EC Partialy on SHU T- check}

The t- check or partials regressiont coefficients check used to determined whether partialy the independently variables a significants effects on the dependently variables or not. To know the effects of EC partialy on SHU, a partial statistical check can be done ensuing:

Be based probability values (p-values). The hypothesist check :

$\mathrm{H}_{0}$ : Partialy EC doesn't have a significants effects on SHU

$\mathrm{H}_{1}$ : Partialy EC has a significants effects on SHU

The hypothesist check terms :

If the p-values $<0.05$; so $\mathrm{H}_{0}$ is rejected and $\mathrm{H}_{1}$ is received

If the $\mathrm{p}$-values $>0.05$; so $\mathrm{H}_{0}$ is received and $\mathrm{H}_{1}$ is rejected

In this matter partialy whether the EC variables a significants effects or not on the SHU. For more detail, look the table ensuing:

Table 2. The Effects of EC on SHU

\begin{tabular}{lrlrc}
\hline \hline \multicolumn{1}{c}{ Variable } & Coefficient & Std. Error & t-Statistic & Prob. \\
C & 26.88912 & 3.114594 & 8.633266 & 0.0000 \\
\multicolumn{1}{c}{ EQUITY_CAPITAL } & -0.044036 & 0.018500 & -2.380296 & 0.0205 \\
& Effects Specification & & \\
Cross-section fixed (dummy variables) & & & \\
R-squared & 0.746707 & Mean dependent var & 20.59978 \\
Adjusted R-squared & 0.617914 & S.D. dependent var & 25.30822 \\
Sum squared resid & 14438.96 & Schwarz criterion & 9.465687 \\
F-statistic & 5.797738 & Durbin-Watson stat & 2.202137 \\
Prob(F-statistic) & 0.000000 & & \\
\end{tabular}

\section{Sumber: diolah dengan Eviews}

At table 2 above, can be observed that the probabilities values of EC or p-values EC is $0.0205<0.05$ so $\mathrm{H}_{0}$ is rejected and $\mathrm{H}_{1}$ is received, signify EC has a significants effects on SHU.

Ratio of t-count with t-table. Hypothesist check is:

$\mathrm{H}_{0}$ : Partialy EC hasn't effects on SHU

$\mathrm{H}_{1}$ : EC partialy effects on SHU

The hypothesist test terms:

If $\mathrm{t}>\mathrm{t}$-table, so $\mathrm{H}_{0}$ is rejected and $\mathrm{H}_{1}$ is received

If $\mathrm{t}<\mathrm{t}$-table, so $\mathrm{H}_{0}$ is received and $\mathrm{H}_{1}$ is rejected

To know values of $t$-table could be obtaine by used the provisiont t-table $=(\alpha ; \mathrm{df})$, wherein $\alpha$ 
values is $5 \%$ or 0.05 and the df values is (nk), wherein $\mathrm{n}$ is the numbers of observationt and $\mathrm{k}$ is the numbers of variable utilized. At table 2 mentioned, it could in view that the t-statistic of the $\mathrm{EC}$ is 2.380296 . Whilst the $\mathrm{t}$-table values is: $\mathrm{t}$-table $=(\alpha ; \mathrm{n}-\mathrm{k})=(0.05 ; 90-4)=(0.05$; $86)=1.66277$. So $t$-count $>$ t-table that is $2.380296>1.66277$ then $\mathrm{H}_{0}$ is rejected and $\mathrm{H}_{1}$ is received, signify that EC partialy has a significants effects on SHU.

\section{Determinationt coefficients check}

The coefficients of determinationt showing the percentages of the independently EC variables using in the models capable to explained the dependents variables SHU. At table 2 above, the dimensions of $\mathrm{r} 2$ is .746707 , this showing that the percentages contributiont of the influences of the independents variables EC to the dependents variables residual income is equals to $74.67 \%$ or it could meaning lest the independents variable utilized in models are able to explained the total $74.67 \%$ to the dependents variables, the rest $25.33 \%$ is affected by others factor beyond the regressiont models.

\section{The Simultaneously Effects of DC and EC on SHU \\ Simultaneously check (F- check)}

Simultaneously check or F- check is utilized check the effects of every independently variable togethers on dependents variables. To check effects of DC and EC simultaneously on SHU, a statistically check of the F-test can be done ensuing:

Be based probability values (p-values). The hypothesist check:

$\mathrm{H}_{0}$ : DC and EC simultaneouly have'n significants effects on SHU.

$\mathrm{H}_{1}$ : DC and EC simultaneouly have a significants influences on SHU

The hypothesist check terms :

If the $\mathrm{p}$-values $<0.05$; so $\mathrm{H}_{0}$ is rejected and $\mathrm{H}_{1}$ is received

If the p-values $>0.05$; so $\mathrm{H}_{0}$ is received and $\mathrm{H}_{1}$ is rejected

In this matter togethers (simultaneouly) whether the DC and EC variables has a significants effects orn't on SHU, look the table ensuing:

Table 3. The Simultaneously Effects of DC and EC on SHU

\begin{tabular}{lrlrc}
\hline \hline \multicolumn{1}{c}{ Variable } & Coefficient & Std. Error & t-Statistic & Prob. \\
\multicolumn{1}{c}{ C } & 20.58069 & 2.972068 & 6.924702 & 0.0000 \\
DEBT_CAPITAL & 0.221438 & 0.046402 & 4.772187 & 0.0000 \\
EQUITY_CAPITAL & -0.153077 & 0.027787 & -5.509050 & 0.0000 \\
& Effects Specification & & \\
Cross-section fixed (dummy variables) & & 20.59978 \\
R-squared & 0.818122 & Mean dependent var & 25.30822 \\
Adjusted R-squared & 0.720911 & S.D. dependent var & 8.295655 \\
S.E. of regression & 13.37004 & Akaike info criterion & 9.184476 \\
Sum squared resid & 10367.97 & Schwarz criterion & 8.654080 \\
Log likelihood & -341.3045 & Hannan-Quinn criter. & 2.339690 \\
F-statistic & 8.415969 & Durbin-Watson stat & \\
Prob(F-statistic) & 0.000000 & & \\
\end{tabular}

\section{Sumber: diolah dengan Eviews}

At table 3 mentioned, could be observed that the probabilities values of F-count is 0.000000 $<0.05$, so $\mathrm{H}_{0}$ is rejected and $\mathrm{H}_{1}$ is received, signify DC and EC togethers (simultaneouly) have a significants effects on SHU. 
Based on ratio of F-count with F-table. Hypothesist check is :

$\mathrm{H}_{0}$ : DC and EC simultaneously have'n effects on SHU

$\mathrm{H}_{1}$ : DC and EC simultaneously have an effects on SHU

The hypothesist test terms :

If F-count $>$ F-table, so $\mathrm{H}_{0}$ is rejected and $\mathrm{H}_{1}$ is accepted

If $\mathrm{F}$-count $<\mathrm{F}$-table, so $\mathrm{H}_{0}$ is accepted and $\mathrm{H}_{1}$ is rejected

To know values of $\mathrm{f}$-table could be obtaine by used the provisiont $\mathrm{f}$-table $=(\alpha ; \mathrm{df})$, wherein $\alpha$ values is $5 \%$ or 0.05 and the df values is (nk), wherein $\mathrm{n}$ is the numbers of observationt and $\mathrm{k}$ is the numbers of variable utilized. At table 3 mentioned, it could in view that the calculate Fvalues is 8.415969. Whilst the f-table values is: $\mathrm{f}$-table $=(\alpha ; \mathrm{n}-\mathrm{k})=(0.05 ; 90-4)=(0.05$; $86)=2.710$. So f-count $>$ f-table that is $8.415969>2.710$ then $\mathrm{H}_{0}$ is rejected and $\mathrm{H}_{1}$ is received, signify that DC and EC simultaneouly have a significants effects on SHU.

\section{Determinationt coefficients check}

The coefficients of determinationt showing the percentage of the independently variable DC and EC using in the models capable to explained the dependents variables SHU. At table 3 above, the dimensions of $\mathrm{r} 2$ is 0.818122 , this showing that the percentages contributiont of the influenced of the independents variables DC and EC to the dependents variables SHU is $81.81 \%$ or it could meaning lest the independents variable utilized in models are able to explained the total $81.81 \%$ to the dependents variables, the rest $18,19 \%$ is affected by others factor beyond the regressiont models.

\section{The Effect of SHU Partialy on Amount Member T-check}

The t-check or partials regressiont coefficients check used to determined whether partialy the independently variables a significants effects on the dependently variables or not. To know the effects of of SHU partialy on amount member, a partial statistical check can be done ensuing:

Be based probability values (p-values). The hypothesist check:

$\mathrm{H}_{0}$ : SHU partially have'n significants effects on amount member

$\mathrm{H}_{1}$ : SHU partially have a significants effects on amount member

The hypothesist check terms :

If the $\mathrm{p}$-values $<0.05$; so $\mathrm{H}_{0}$ is rejected and $\mathrm{H}_{1}$ is received

If the p-values > 0.05 ; so $\mathrm{H}_{0}$ is received and $\mathrm{H}_{1}$ is rejected

In this matter partialy whether the SHU variables a significants effects orn't on amount member, for more details, look the table ensuing: 
Table 4 t-check results (Effect of SHU on Number of Member)

\begin{tabular}{|c|c|c|c|c|}
\hline Variable & Coefficient & Std. Error & t-Statistic & Prob. \\
\hline $\mathrm{C}$ & 861.0400 & 172.2204 & 4.999641 & 0.0000 \\
\hline SHU & -8.795997 & 7.029753 & -2.251253 & 0.0158 \\
\hline \multicolumn{5}{|c|}{ Effects Specification } \\
\hline \multicolumn{5}{|c|}{ Cross-section fixed (dummy variables) } \\
\hline R-squared & 0.418360 & \multicolumn{2}{|c|}{ Mean dependent var } & 679.8444 \\
\hline Adjusted R-squared & 0.122610 & \multicolumn{2}{|c|}{ S.D. dependent var } & 944.1111 \\
\hline S.E. of regression & 884.3402 & \multicolumn{2}{|c|}{ Akaike info criterion } & 16.67418 \\
\hline Log likelihood & -719.3380 & \multicolumn{2}{|c|}{ Hannan-Quinn criter. } & 17.02140 \\
\hline F-statistic & 1.414574 & \multirow{2}{*}{\multicolumn{2}{|c|}{ Durbin-Watson stat }} & 2.302754 \\
\hline Prob(F-statistic) & 0.127135 & & & \\
\hline
\end{tabular}

At table 1 above, can be observed that the probabilities values of SHU or p-values SHU is $0.0158<0.05$ so $\mathrm{H}_{0}$ is rejected and $\mathrm{H}_{1}$ is received, signify SHU has a significants effects on amount member.

Based on ratio of t-count with t-table. Hypothesist check is :

$\mathrm{H}_{0}$ : SHU partialy hasn't significants effects on amount member

$\mathrm{H}_{1}$ : SHU partialy has a significants effects on amount member

The hypothesist test terms :

If $\mathrm{t}$-test $>\mathrm{t}$-table, so $\mathrm{H}_{0}$ is rejected and $\mathrm{H}_{1}$ is received

If $\mathrm{t}$-test $<\mathrm{t}$-table, so $\mathrm{H}_{0}$ is received and $\mathrm{H}_{1}$ is rejected

To know values of t-table could be obtaine by used the provisiont t-table $=(\alpha ; \mathrm{df})$, wherein $\alpha$ values is $5 \%$ or 0.05 and the $\mathrm{df}$ values is (nk), wherein $\mathrm{n}$ is the numbers of observationt and $\mathrm{k}$ is the numbers of variable utilized. At table 2 mentioned, it could in view that the t-statistic of the SHU is -2.251253 , a negative sign indicates a negative or opposite relationships. Whilst the $\mathrm{t}$-table values is: $\mathrm{t}$-table $=(\alpha ; \mathrm{n}-\mathrm{k})=(0.05 ; 90-4)=(0.05 ; 86)=1.66277$. So $\mathrm{t}$-count $>$ t-table that is $2.251253>1.66277$ then $\mathrm{H}_{0}$ is rejected and $\mathrm{H}_{1}$ is received, signify that SHU partialy has a significants effects on amount member.

\section{Determinationt coefficients check}

The coefficients of determinationt showing the percentage of the independents SHU variables using in the models capable to explained the dependents variables amount Member. At table 4 mentioned, dimensions of $\mathrm{r} 2$ is 0.418360 , is showing the percentages of the contributions of the independents variables influence SHU to the member dependents variables is $41.82 \%$ or it could meaning lest the independents variable utilized in models are able to explained the total $41.82 \%$ to the dependents variables, the rest $58.18 \%$ is affected by others factor beyond the regressiont models.

\section{CONCLUSSION AND SUGESTION}

The researchs is to find out the effects of DC and EC on residual income (SHU) and it is impact on amount coperative member. Based on the result of the check and discussiont above, so can be conclussion terms:

1. DC partialy significants effects on SHU. Total of effects of DC on SHU is $72,29 \%$, the rest $27,71 \%$ affected by others factor. 
2. EC partialy has a significants effects on the opposites directions to SHU. Total of effects of EC to SHU is $74,67 \%$, the rest $25,33 \%$ affected by others factor.

3. DC and EC togethers (simultaneouly) have a significants effects on SHU. Total of effects of DC and EC simultaneouly to SHU is $81,81 \%$, the rest $18,19 \%$ affected by other factor.

4. SHU partialy significants effects in the opposites directiont amount member. Total of effects of SHU to amount members is $41,82 \%$, the rest $58,18 \%$ affected by other factor.

Researchers provide suggestions terms:

1. Further research, researchers should add units of analysis and use a longer period, by reason of by utilizing more units of analyziz and a longer periode, more significants research result can be got.

2. Keep in mind highly influences of capital on the growt of SHU, therefore coperative manager must continues to increased the amount of coperative capital they possess, both in the form of EC participation and DC, so that SHU obtained every years will grow and increased.

3. Coperative member as owner and user of coperative servicess should continues to play an activitis role, by reason of advancement or decline of a coperative inseparable from the activity of its members.

\section{REFERENCES}

Alvin Dan Hendang T. 2019. "Pengaruh Corporate Governance (CG) Terhadap Kualitas Laba Dengan Manajemen Laba Sebagai Variabel Intervening Pada Perusahaan Manufaktur Yang Yang Terdaftar Di Bei Periode 2015-2017.” Jurnal Muara Ilmu Ekonomi Dan Bisnis Universitas Tarumanagara Jakarta 3(2):267-88.

Anon. N.D. "Undang-Undang Nomor 25 Tahun 1992 Tentang Perkoperasian."

Buchari, Imam. 2020. "Pengaruh Jumlah Anggota Dan Volume Usaha Terhadap Sisa Hasil Usaha Koperasi Di Wilayah Indonesia Bagian Timur." MSDJ : Management Sustainable Development Journal Volume 2(2):69-86.

Cahyaningrum, Hesti, A. Mulyo Haryanto. 2012. "Analisis Manfaat Working Capital Dalam Memprediksi Pertumbuhan Laba (Studi Kasus: Perusahaan Manufaktur Yang Terdaftar Di Bursa Efek Indonesia Periode 2005 Sampai Dengan 2010).” Eprints.Undip.Ac.Id/35673/1/Jurnal.

Haslinda, Et. A. 2020. "Hubungan Antara Hutang Dan Kinerja Perusahaan Manufaktur Di Indonesia Yang Go Public Tahun 2016 - 2018." Jurnal Muara Ilmu Ekonomi Dan Bisnis Universitas Tarumanagara Jakarta 4(1):10-20.

Henry Yahya. 2015. "Analisis Pengaruh Working Capital Terhadap Prediksi Pertumbuhan Laba Perusahaan.” Universitas Bakrie Indonesia 3(3).

Herdianto, Januar. 2013. Peranan Koperasi Dalam Perekonomian Indonesia. Bekasi: Galaksi.

Irawati, Susan. 2006. Pengaruh Efesiensi Modal Kerja Terhadap Profitabilitas. Bandung: Aksara.

Kartawinata, Budi R., dkk. Manajemen Keuangan (Sebuah Tinjauan Teori dan Praktis). Widina Bhakti Persada Bandung, 2020.

Lucia Ari Diyani, Devi Riana. 2016. "Pengaruh Modal Kerja (Working Capital) Dalam Memprediksi Perubahan Laba Pada Industri Farmasi (Studi Kasus Pada Bei Tahun 2011 - 2014).” Jurnal Online Insan Akuntan, 1(11).

Munawir. 2004. Analisa Laporan Keuangan. Yogyakarta: Liberty.

Ni Made Taman Ayuk, I. Made Suyana Utama. 2011. "Pengaruh Jumlah Anggota, Jumlah Simpanan, Jumlah Pinjaman Dan Jumlah Modal Kerja Terhadap Sisa Hasil Usaha (SHU) Koperasi Simpan Pinjam (KSP) Di Kabupaten Badung Provinsi Bali." 629-46. 
Pertiwi, Maharani. 2017. "Analisis Pengaruh Modal Sendiri, Modal Pinjaman Dan Volume Usaha Terhadap Sisa Hasil Usaha Koperasi Di Kota Surabaya Pada Tahun 2013-2015.” University Of Brawijaya Malang.

Raidayani, Et. A. 2017. "Faktor-Faktor Yang Mempengaruhi Sisa Hasil Usaha (Shu) Pada Koperasi Di Kabupaten Aceh Barat.” Jurnal Perspektif Ekonomi Darussalam 3(2):10116.

Riyanto, Bambang. 2007. Dasar-Dasar Pembelanjaan Perusahaan. Edisi Ke E. Yogyakarta: BPFE.

Syarifuddin. 2019. "Pengaruh Kualitas Layanan, Kepercayaan Dan Sisa Hasil Usaha Terhadap Kepuasan Anggota Koperasi Bank Rakyat Indonesia Cabang Mamuju." Growth Jurnal Ilmiah Ekonomi Pembangunan 1(1):39-55.

Tria Rohmansyah, Sudarijati. 2017. "Pengaruh Modal Sendiri Dan Modal Pinjaman Terhadap Sisa Hasil Usaha (Shu) Koperasi Kota Sukabumi.” Jurnal Visionida 3(1):53-65. 